\title{
RELATIONAL CONTRACTING AND ITS COMBINATION WITH THE BIM METHODOLOGY IN MITIGATING ASYMMETRIC INFORMATION PROBLEMS IN CONSTRUCTION PROJECTS
}

\author{
António MARINHO $\mathbb{D}^{*}$, João COUTO ${ }^{\circledR}$, José TEIXEIRA $(\mathbb{D}$ \\ Department of Civil Engineering, School of Engineering, University of Minho, Guimarães, Portugal
}

Received 9 December 2020; accepted 3 March 2021

\begin{abstract}
Project management in the construction sector is a complex and uncertain process and companies tend to look for the lowest value in the procurement of services and materials. However, contractors do not share the necessary information with the contracted parties and thus give rise to the asymmetric information (AI) phenomenon. The aim of this study is to perform an analysis of the determining factors in the adoption of relational contracting (RC) in combination with Building Information Modelling (BIM) to reduce AI. The results of a questionnaire survey, which was e-mailed to 14 specialists with solid experience (over twenty years) and knowledge in construction projects, revealed that the probability of the AI phenomenon occurring in Portugal is very high, and its impact on construction projects is equally high. The results also show that RC in combination with the BIM methodology contributes very positively to the mitigation of AI problems in construction projects in Portugal. Approximately $85 \%$ of respondents consider that the government should seek to reduce $\mathrm{AI}$ in the public works sector through the use of RC and its combination with the BIM methodology in the Portuguese Public Contracts Code.
\end{abstract}

Keywords: BIM, construction projects, relational contracting, asymmetric information, Portugal.

\section{Introduction}

Some authors explain project management (PM) as a methodology based on applying knowledge, skills, tools, and techniques to project activities in response to their specific requirements. In brief, each activity receives an input, adds value to it, uses the organization's resources and produces an output to generate a specific result (Dumouchel et al., 2004; Morais et al., 2015; Project Management Institute [PMI], 1996, 2018). However, the vulnerability of construction projects often means many activities that imply distinct categories of knowledge. For example, most construction projects are subject to climate specificities and this only factor may involve uncertainties associated with the duration and productivity of activities in construction projects and can therefore hinder their success (Ac1kara et al., 2017).

Xiang et al. (2015) considers that PM in the construction sector is a complex and uncertain process: for example, when procuring a service or ordering a material, there is a tendency to use the same contracting methodology regardless of the project's specific requirements. Ning and Ling (2015) point out that companies, when procuring services and materials, always seek the lowest price, thus increasing the inefficiency of the sector and giving rise to criticisms associated with a low level of productivity and innovation. Some authors suggest that the main cause of these problems in the sector stems from the fact that contractors do not share the necessary information with the contracting parties regarding the construction project, thus preventing both parties from getting involved in an integrated manner and developing a close relationship (Ling et al., 2014; Xiang et al., 2015).

From the perspective of the economy, restriction on access to information gives rise to the so-called asymmetric information (AI) phenomenon. This asymmetry occurs when two or more economic agents establish a transaction between themselves and one of the parties holds more information than the other (Arrow, 1978; Xiang et al., 2015). It was Arrow (1978) who first presented this concept in 1963, suggesting that, in the context of economic activities, the parties may deliberately hide part of the information in order to protect their own interests. But in 1970 Akerlof introduced and analysed the impact

*Corresponding author. E-mail: am4engenharia@gmail.com 
of AI in the market failure problem (Akerlof, 1970). Later, Rothschild and Stiglitz (1976) addressed the role of AI in the context of job market and insurance, showing that agents can send signals to mitigate the effect of informational asymmetry (Spender, 1993). The basic idea is that agents trade in the market because they share mutual benefits. However, when the AI increases up to a certain level, high-quality goods drop out from the market and only low-quality goods can be traded. This situation is called adverse selection (Biglaiser \& Friedman, 1999; Bloodgood \& Salisbury, 2001; Tilles et al., 2011). The complexity of both the market and human behaviour makes it difficult to build mathematical models able to be applied in realworld situations. The challenge consists in incorporating AI into mainstream of the standard economic theory. To solve the this problem, Ling and Tran (2012) consider that the use of relational contracting (RC) as a procurement method is beneficial because it produces better results due to greater involvement of the contractor in the project.

The concept of RC was identified by Sanders and Moore (1992), who categorized two types of contracts based on the procurement of services or materials: individual contracting (IC) and RC. In IC, stakeholders usually proceed independently, focusing on their own interests; in turn, $\mathrm{RC}$ is underpinned by different approaches that establish working relationships between the contractor and the contracting party and thus promotes win-win situations. However, in recent years there have been developments and adaptations of collaborative tools and methodologies in the construction sector. For example, the Building Information Modeling (BIM) methodology, or simply BIM, described as a socio-technical system (Sackey et al., 2015) (as it is composed of technical dimensions such as 3D modelling, planning and cost), has led to changes in the way designers and builders share information (Liu et al., 2017).

The aim of this study is to conduct an analysis of the characteristics of RC and its relevance in combination with the BIM methodology in construction projects to reduce AI. The following research questions were identified: Q1 - "How does RC positively affect the reduction of AI in public works construction projects? What are the main characteristics of RC?"; Q2 - "How does RC in combination with $B I M$ positively affect the reduction of AI in public works construction projects? What are the main characteristics of $R C$ in combination with BIM?"; Q3 - "Does the Portuguese legislation provide for the reduction of AI in public works construction projects?".

Through a literature review, several characteristics of $\mathrm{RC}$ and its combination with the BIM methodology were collected. To understand the experts' perception of the importance of RC and its combination with the BIM methodology on mitigating AI in construction projects in Portugal, surveys were developed and implemented via the Internet. In the selection of the population, we took into consideration the technicians with expertise in construction direction and management that have participated in BIM methodology-based RC projects from the 50 largest companies in the building construction and built heritage sector in Portugal according to PORDATA, the Portuguese Database with the major companies in Portugal, resulting into 14 specialists.

The subsequent sections are organized as follows: Section 1 describes the review of the state of the art; Section 2 presents the research methodology implemented in this study; Section 3 presents and discusses the results obtained; finally, last Section presents the main conclusions of the work conducted within this study.

\section{Literature review}

\subsection{Characteristics of asymmetric information}

In general, one can say that uncertainty is the main element that complicates construction projects, as it creates a need for adaptation in situations characterized by incomplete and asymmetric information (Wang et al., 2017; You et al., 2018) and may even give rise to opportunistic behaviour on the part of the contractor in order to achieve his own gains at the expense of the contracting party. For example, You et al. (2018) state that uncertainty subjects trade to opportunistic behaviour that can be avoided by implementing RC. In recent years, the uncertainty factor in construction projects has led researchers to deepen the impact of $\mathrm{AI}$ in the construction sector (Xiang et al., 2015).

The asymmetric influence is defined through moral hazard or adverse selection (You et al., 2018). Moral hazard exists when an agent is exposed to unpredictable events that may affect his performance and induce him to make less effort - because there is an incentive to make less effort - and to blame his failure on the unpredictable event and not on his own lack of effort (Xiang et al., 2015; You et al., 2018). There is adverse selection when you cannot distinguish good products (or good workers, or more careful customers) from bad products (or bad workers, or less careful customers). A major difference that should be noted is that moral hazard arises "after the contract" and adverse selection "before the contract". Moral hazard can also be viewed as an incompletely specified contract that does not cover all types of behaviour. In this regard, moral hazard in RC can be viewed as an incompletely specified contract. For example, customers may determine a base price for the bid that is reasonable in order to eliminate malicious bids and choose the one with the most advantageous price-quality (Xiang et al., 2012).

The existence of private information makes the distribution of AI among the entities, therefore our study relates to literature on the principal-agent theory, which is usually used in the design of incentive mechanisms ( $\mathrm{Su}$ et al., 2020). According to Bovens et al. (2014) the principal-agent theory encapsulates a rational choice modelling where the principal uses whatever actions to provide incentives for the agent to make decisions that the principal most prefers. Laffont and Martimort (2009) proposed the theory of incentive based on the principal-agent frame- 
work, and stated that the need for proper incentive mechanisms appears when the principal hires an agent who has superior information. By testing principal-agent theory in buyer-supplier relationships, Su et al. (2020) found that both ex ante and ex post forms of opportunism can explain the occurrence of moral hazard.

Chang and Shen (2014) points out that to control the probability of AI occurring, the project owner can promote a collaborative bidding process, i.e., he can provide a fairtrading platform and thus strengthen the dissemination of information and knowledge. On the other hand, more emphasis should be placed on relational approaches in the execution phase to prevent contractors from incurring in "moral corruption" even when they seek to maximize their profits (Xiang et al., 2012). The relational approach has been explored in the literature of organizational studies from a predominantly functional perspective and much of the research emphasizes its potential benefits and purposes (Hardy \& Phillips, 1998) when it involves sharing information in decision-making and sharing data and resources (Popp et al., 2004).

\subsection{Relevance of relational contracting in reducing asymmetric information}

Walker and Lloyd Walker (2015) group in three main categories the most commonly used contractual arrangements in the construction sector: (i) separation of design from construction responsibilities: Design-Bid-Build (DBB), which is the best-known model - it separates design from build and has the advantage of not entailing the risk of coordination for the client, but still the contractor does not add knowledge in the design phase (Chappell \& Parkin, 2004; Ribeiro, 2012); (ii) project delivery with a focus on planning and control: Design-Build (DB) and PublicPrivate Partnerships (PPP), two models characterized by the fact that there is only one organization responsible for design and build, although the client has no control over the construction project (Chappell \& Parkin, 2004; Healy, 2007); (iii) delivery of the integrated project - Integrated Project Delivery (IPD), focused on collaboration, partnerships, coalitions and RC. The project owner delegates control of the project and acts in collaboration with the various stakeholders, and the contractor adds knowledge in the design phase (Hosseini et al., 2017).

According to Liu et al. (2017), the most commonly used contracts in the construction sector are the DBB type, which can give rise to $\mathrm{AI}$ (adverse selection) between the contractor and the contracting party and therefore cause the information holder to behave opportunistically when approaching the other party. On the other hand, as the contracting parties are less experienced, a more informed and experienced supplier or contractor may tend to adopt opportunistic behaviour. Hence the importance of RC, as it allows for information transfer, knowledge creation, technological coordination, and resource allocation in order to operate effectively and thus minimize potential conflicts in the implementation of construction projects. Therefore, it is important to establish effective management mechanisms, such as RC, to reduce potential opportunistic behaviours, both on the part of the contractor and the contracting party (Yiu et al., 2018).

The IPD method began to be implemented in practice when in 2007 the American Institute of Architects (AIA) introduced this new system of project delivery that promotes a more efficient performance via a greater integration of the various stakeholders (Mesa et al., 2016). The IPD consists of an alternative and highly collaborative contractual agreement (American Institute of Architects \& Associated General Contractors of America, 2004; Kent \& Becerik-Gerber, 2010; Mihic et al., 2014) between at least three main parties involved in the project: the client, the designer, and the contractor; it requires the use of the BIM methodology and the integration of technology in the contract (Mihic et al., 2014; Raisbeck et al., 2010); it promotes high performance of the teams involved by aligning incentives and goals; and increases the construction project's final value to the client by reducing waste and promoting the relationship between the stakeholders (Kent \& Becerik-Gerber, 2010; Raisbeck et al., 2010). While the IPD may have advantages over other procurement methods regarding certain types or dimensions of construction projects, the literature suggests, however, that it may produce disadvantageous results in less complex and smaller projects (Mesa et al., 2016). Lévy (2011) states that a major factor for the success of the IPD is open and honest communication between stakeholders, which results in increased value for the customer and reduced construction waste. In other words, lower information and transactions costs increase alignment of incentives and increase efficiency in that at least one-party benefits (namely, in terms of lower costs) and the other party loses.

Some authors consider nine fundamental principles to obtain the maximum benefits from the IPD (American Institute of Architects \& Associated General Contractors of America, 2004; Kent \& Becerik-Gerber, 2010; Mihic et al., 2014): 1) a multi-party agreement; 2) mutual respect and trust; 3) mutual benefits and rewards; 4) collaborative innovation and joint decision-making; 5) initial involvement of key stakeholders; 6) setting goals at the beginning of the project; 7) intensified planning; 8) open communication; and 9) effective organization and leadership in construction project management.

The IPD involves transactional contracts and relational contracts. Externally, stakeholders enter a classic transactional contract with the client and some suppliers, and internally they are bound by a relational contract described in the procurement document signed by all parties. The relational contract minimizes the cost of the transaction by uniting the stakeholders in a partnership for the duration of the project. In other words, the IPD is a RC approach that aligns the project goals with the stakeholders' interests (Matthews \& Howell, 2005). Relational contracting is relevant to the IPD methodology because changing assumptions about the stakeholders' behaviours and motivations allows envisaging and addressing many of 
the problems associated with public-private supply (Hrelja et al., 2018). Piroozfar et al. (2019) also point out that collaboration and trust are the most important factors of the IPD methodology in the project's initial stage. The absence of these two factors is identified in the literature as the main barrier to implementing the IPD methodology. As a non-pecuniary instrument, moral appeals are outside standard economic cost-benefit analysis. Their monetary costs are typically small, they are fast to implement, and they can complement economic incentives or commandand-control regulations. By affecting social norms or the adherence to norms (Acıkara et al., 2017; Young, 2015), moral suasion is expected to increase individual contributions to reduce externalities or to contribute to a public good in absence of more rigorous governmental interventions and may also increase support for and compliance with regulations. Young (2015) also refers that social norms are patterns of behaviour that are self-enforcing within a group: Everyone conforms, everyone is expected to conform, and everyone wants to conform when they expect everyone else to conform.

According to $\mathrm{Gu}$ and London (2010), RC is similar to partnerships and coalitions because a temporary organization is created from individual entities, but differs in its approach by way of compensation, risk sharing and decision-making by both parties. In RC, both parties may agree to limit liability between them because if they make mistakes the insurance is expected to respond. But what happens if the insurance contract is not fully specified, so that all contingencies are not covered? Also, are there deductibles of some sort in the insurance contract, or RC for that matter, to address the moral hazard problem? Decisions are developed as a team, but the project owner usually holds the final decision rights in the absence of team consensus. As discussed by Halttula et al. (2015), traditional methods prove ineffective and impose on the construction industry the need to use other methods, such as RC, to establish a mutual goal. For these authors, the main characteristic of $\mathrm{RC}$ is the distribution of the project's responsibilities and risks, which corroborates the interpretation by $\mathrm{Gu}$ and London (2010). Shared values, restricted participation, meetings and collective sanctions help companies to demonstrate their commitment to the projects and disseminate information among all stakeholders (Grafton \& Mundy, 2017). Traditional contracts are exposed to moral hazards and AI problems (Alon et al., 2015; Hart, 2017) that can create difficulties to the construction industry. On occasions, it is difficult to verify contract performance based on its original provisions, and parties in a long-term relationship may rely on incentives contracts that are self-enforced or relational (Doornik, 2006). Due to the internal and external dynamics of this economic relationship, it is important that parties have room to re-negotiate. Relational contracting theory is well suited to underpin the behaviour between both parts as they look to find equilibrium over their governance and performance. RC are more fit to govern trust and commitment-based relationship in construction partnerships, and to help construction partnerships be more efficient and stable, which can lead to international franchise expansion and group performance.

Musawir et al. (2020) conducted a systematic review of the literature on project governance and its role in strategic organizational implementation and found that most quantitative research remains focused on contractual and relational governance. For their part, Herz et al. (2019) conducted a study on the factors of cooperation and mistrust in relational contracts and verified that labour and commercial relations are often governed by relational contracts, in which the incentives for cooperation derive from the future benefits expected from this relationship. By comparing the relationship between the contractor and the contracting party with verifiable and non-verifiable information about the contractor's costs, they found that non-verifiable information affects the terms of the relational contracts; however, the party that is negatively affected by these adjustments does not originate a reduction of efficiency.

In a study conducted by Hosseini et al. (2017) are mentioned the four main characteristics of relational contracts in the construction sector: (i) common incentives; (ii) involvement of the contractor from the initial stage; (iii) cooperation between the parties involved; and (iv) its significant importance in complex projects. These authors also stress that the main reasons for clients to choose RC are, firstly, to improve the attitude of project participants and reduce the occurrence of disputes, changes in scope, rework, and possible incidents; and, secondly, the change, complexity of projects and uncertainty in projects.

The more uncertainty in the projects, the greater the possibility of AI, especially moral hazard from incompletely specified contracts, including insurance, more disputes and scope changes, but relational contracts can foster a collaborative environment and establish a common purpose for all project stakeholders. Rahman and Kumaraswamy (2002) argue that the appropriate contracting method, based on clear and equitable contractual documents, does not guarantee the success of a project, because the attitudes of the contracting parties and the relationships between project participants are equally important. Another stream of research tries to find out whether intrinsic or extrinsic motivation is the cause of behaviour. Gneezy et al. (2011) examined the importance and effectiveness of external incentives to induce a certain behaviour. Not only may offering a positive incentive shift the review-writing decision from social to monetary, but it may also break social norms of trust as the explicit incentive can signal a marketer's attempt to manipulate prosocial customer behaviour. Schmidt and Wagner (2019) stress that RC can be useful in reducing information costs (defined as costs of negotiating, writing and ensuring compliance with a contract), in promoting corporate relationships and more efficient teamwork.

Table 1 summarizes the main characteristics of RC, found in the literature review, which contribute to reducing asymmetric information in construction projects. 
Table 1. Main characteristics of RC that contribute to reducing AI

\begin{tabular}{|l|l|}
\hline \multicolumn{1}{|c|}{ Characteristics of RC } & \multicolumn{1}{c|}{ Authors } \\
\hline Transfer of information in the initial phase of the project & Liu et al. (2017) \\
\hline Creation of knowledge in the initial phase of the project & Liu et al. (2017) \\
\hline Reduction of conflicts between the parties involved & Liu et al. (2017) \\
\hline Technological coordination between the parties involved & Liu et al. (2017) \\
\hline Allocation of resources to operate effectively & Liu et al. (2017) \\
\hline Risk sharing between the parties involved & Gu and London (2010), Halttula et al. (2015) \\
\hline Distribution of responsibilities and risks between the parties involved & Halttula et al. (2015), Hosseini et al. (2017) \\
\hline Future relations between the parties involved & Halttula et al. (2015), Hosseini et al. (2017) \\
\hline Common incentives between the parties involved & Grafton and Mundy (2017), Hosseini et al. (2017) \\
\hline Involvement of the contractor in the initial phase of the project & Grafton and Mundy (2017), Hosseini et al. (2017) \\
\hline Cooperation between the parties involved & Hosseini et al. (2017) \\
\hline Its relevance in complex projects & Hosseini et al. (2017) \\
\hline Improving the attitude of project participants & Hosseini et al. (2017), Rahman and Kumaraswamy (2002) \\
\hline Reduction of disputes between the parties involved & Hosseini et al. (2017), Rahman and Kumaraswamy (2002) \\
\hline Reduction of unnecessary work & Hosseini et al. (2017), Rahman and Kumaraswamy (2002) \\
\hline Promotion of teamwork & Rahman and Kumaraswamy (2002) \\
\hline Reduce of transactions and information costs & Fanning et al. (2015) \\
\hline Intrinsic or extrinsic motivation & Gneezy et al. (2011) \\
\hline
\end{tabular}

\subsection{Relational contracting in combination with the BIM methodology in reducing asymmetric information}

BIM is a methodology with its own characteristics that affect project procedures (Halttula et al., 2015). The main function of the BIM methodology is to enable users to integrate, analyse, simulate and visualize a building's geometric or non-geometric information (Grilo \& Jardim-Goncalves, 2010), and has been recognized as one of the most appropriate platforms for the Architecture, Engineering and Construction (AEC) industry (Li et al., 2017) by promoting the integration of stakeholders and correcting problems that occur in the flow of data and information (Nathan \& Scobell, 2012; Succar, 2009). The BIM have an impact on the consumption of building energy, by optimized building design and construction and operating management. For example, BIM contribute to a successful integration of photovoltaic technologies (building integrated photovoltaic and building attached/applied photovoltaic) which generates benign energy by harnessing abundant, inexhaustible, clean solar power (Ghosh, 2020). The BIM methodology is the current expression of digital innovation in the construction sector (Succar \& Kassem, 2015).

Communication between project stakeholders has also been altered by the introduction of the BIM methodology in the construction sector to facilitate the sharing of information, knowledge and technology among the various stakeholders throughout a project's life cycle (Holmström et al., 2015). Although construction projects are heavily dependent on the knowledge that each of the various stakeholders contributes to successful delivery and decision-making (Mok \& Shen, 2016), there is still a lack of efficient guidelines for collaboration among the various specialties in all the project's stages (Kurwi et al., 2017). Therefore, the challenge is to develop a collaboration model to improve communication among the various stakeholders and thus promote greater adoption of BIM in the construction sector (Wang et al., 2020).

The IPD is a project delivery approach interconnected with BIM (Piroozfar et al., 2019). The BIM methodology is advocated in many scientific articles (Azhar, 2011; Azhar et al., 2012) due to the main fact of improving communication among stakeholders. The IPD was introduced in the United States (Mihic et al., 2014) to establish in the construction sector a different paradigm than traditional procurement systems, aiming to reducing project's cost, duration, and quality. According to the American Institute of Architects (AIA), although BIM can be implemented in most procurement systems, this methodology is more appropriate when implemented within the framework of IPD, as the combination of the two methodologies favours the transition from the traditional paradigm to the modern paradigm.

In recent years there have been some developments that highlight the use of the BIM methodology as a collaborative tool (Liu et al., 2017) to create an information centre for the life cycle of projects (Mihic et al., 2014), where stakeholders add information or knowledge to the model (Hrelja et al., 2018), from which all the necessary documents are then extracted of focal points, including the impact upon information and transactions costs, for example, game theory is often used to study the relationship among engineering project stakeholders and resolve conflicts (Rzepecki, 2021). The review of modern application of a game theory has shown the wide spectrum 
of its use supporting decision making. Models based on the game theory were applied for renewal of construction objects, analysis of bidding procedure and profit distribution in construction projects and the need to support the negotiation processes in a construction industry was recognized (Anysz, 2019; Rzepecki, 2021).

Therefore, the interdependence between all the participants in the sector is extended and direct, starting with the project and then with planning/management, construction, and maintenance (Piroozfar et al., 2019). IPD, thought a relatively new and still evolving project delivery system, emphasises on the involvement of key participants, relationships, collaboration and the pursuit of mutual goals (Hamidavi et al., 2020). Nevertheless, evidence shows that few projects adopt IPD, due cultural, financial, legal and technological barriers (Teng et al., 2017). One of the keys to IPD success includes mutual profit and reward that motivates stakeholders. Studies have been conducted in the field of fair distribution of profits, and IPD has been more successful in this regard (Li et al., 2017; Teng et al., 2017).

BIM distinguished from other methods by integrating all those involved in the design of the architectural project and specialties, and therefore adding value to the project. BIM is used in combination with the other methodologies, but is highly recommended, and deeply advantageous, when combined with the IPD (Marinho, 2014; Ribeiro, 2012). The IPD reduces the barriers regarding in the implementation of BIM, because it removes the contractual and responsibility separations and consequently favours the collaboration environment necessary for the effective implementation of BIM (Azhar et al., 2012). According to Jones (2014), the combination of the IPD with the BIM methodology allows optimizing the construction project in terms of sustainability - and this explains why BIM is considered an essential tool for the construction sector. BIM is also important for the IPD, as it provides a threedimensional model of the project before its construction, allowing stakeholders to clearly analyse the project (Lévy, 2011; Mihic et al., 2014).

Fanning et al. (2015) found that BIM promotes the process of interdisciplinary cooperation and communication in a construction project and contributes to the reduction of errors through knowledge sharing. Kurwi et al.
(2017) noted that collaboration can enhance productivity, as cooperation between multidisciplinary teams contributes to the reduction of project errors.

The greatest advantage of using $\mathrm{RC}$ in combination with the BIM methodology is the reduction of conflicts between the various stakeholders throughout the life cycle of construction projects. Projects using RC require the designer and the contractor to work together in the initial phase. Thus, the BIM methodology can be the link that enables this integration between project stakeholders, therefore promoting effective and fluid communication between the various parties involved (Halttula et al., 2015).

However, several professional entities have started to develop addenda to their contracts and to define the responsibilities of the teams using the BIM methodology. These addenda allow clients, architects, engineers, and builders to obtain a guide to develop a specific project using the BIM methodology. As an example, in 2008 the American Institute of Architects (AIA) and the Associated General Contractors of America (AGCA) created the first addendum, called E202 (Hardin \& McCool, 2015). Kent and Becerik-Gerber (2010) show that the experience of construction professionals has been optimized by using $\mathrm{RC}$ in combination with the BIM methodology or exclusively with RC in their construction projects. Although it may seem that the BIM methodology is used more in RC-based contracts, the industry professionals emphasize that BIM is not a prerequisite for RC. The same authors (Kent \& Becerik-Gerber, 2010) also stress that there are still cultural, social norms, procedural and organizational barriers to the widespread use of RC in the construction sector. Through interviews with a group of experts in the use of the BIM methodology, Liu et al. (2017) identified eight characteristics that influence the development of the collaborative process using the BIM methodology: (i) information technology capability; (ii) technology management; (iii) attitude and behaviour; (iv) roles and responsibilities; (v) trust; (vi) communication; (vii) leadership; and (viii) learning and experience.

Table 2 summarizes the main characteristics of RC in combination with the BIM methodology, identified in the literature review, which contribute to reduce AI in construction projects.

Table 2. Main characteristics of RC in combination with the BIM methodology in reducing AI

\begin{tabular}{|l|l|}
\hline \multicolumn{1}{|c|}{ Characteristics of RC in combination with the BIM methodology } & \multicolumn{1}{c|}{ Authors } \\
\hline Corrects problems in data flow & Nathan and Scobell (2012), Succar (2009) \\
\hline Facilitates adding information to the model & Arayici et al. (2009), Halttula et al. (2015) \\
\hline Interdependence between all project participants & Addor et al. (2010) \\
\hline Integrated activities with a single and mutual goal & Li et al. (2017), Halttula et al. (2015), Liu et al. (2017) \\
\hline Involvement of designers and contractor to increase value for the client & $\begin{array}{l}\text { Halttula et al. (2015), Liu et al. (2017), } \\
\text { Hardin and McCool (2015) }\end{array}$ \\
\hline Increased communication between the parties involved & Liu et al. (2017), Hardin and McCool (2015) \\
\hline Definition of roles and responsibilities & Liu et al. (2017) \\
\hline
\end{tabular}




\subsection{European and national legislation on the use of collaborative systems in combination with BIM}

The use of the BIM methodology is much diversified at international level. The Nordic countries were the most advanced at an early stage, followed by the UK and Ireland, but there is now a general willingness to implement the BIM methodology worldwide through a series of public policies aimed at improving the efficiency of the construction industry (Charef et al., 2018). At the European level, Directive 2014/24/EU (2014) of the European Parliament and of the Council on public procurement establishes the need to use the BIM methodology for construction projects financed by public funds (Charef et al., 2018).

The implementation of the BIM methodology provided for in Directive 2014/24/EU (2014) has the specific goal of assessing and overcoming legal, regulatory, politi$\mathrm{cal}$ and public procurement barriers in order to promote collaborative work and data sharing (EuBIM TaskGroup, 2017) and introduce major changes in business and PM practices (He et al., 2017). In 2017, the European Union released a manual, prepared with the collaboration of 21 countries, on the application of the BIM methodology in the public sector in order to make construction costs lower and more rigorous and reduce delays in the execution of construction projects. As such, governments, being the largest contracting entities, can influence and encourage innovation regarding procurement procedures (EuBIM TaskGroup, 2017).

The Portuguese Public Contracts Code (PCC) is based on the ninth amendment through Decree-Law 111-B/2017 which transposes the abovementioned Directive 2014/24/ EU (2014) and provides for the possibility of using the BIM methodology or other electronic means of modelling construction data. However, this law is silent on its specificity or the procedure for its adoption and implementation. Regarding procurement criteria, the best price-quality ratio is assessed through a cost-effectiveness analysis, including life cycle costs. The legislation also provides for the introduction of a designated contract manager whose function is to permanently monitor the execution of the construction project (SPMS, 2017).

\section{Research methodology}

Comprehensive research was carried out through the analysis of journal and conference papers mainly published between 2013 and 2018, related to RC, the BIM methodology and reduction of information asymmetry in the construction sector, but older papers were also analysed due to their important contribution. This research used Science Direct database based on the following keywords in different combinations: "asymmetric information", "relational contracting", "BIM", and "construction projects". Based on the literature review, the main characteristics of relational contracting $(\mathrm{RC})$ and the advantages of its combination with the BIM methodology for reducing asymmetric information were identified.
To understand the experts' perception of the importance of RC and its combination with the BIM methodology in mitigating AI in construction projects in Portugal, surveys were developed and sent via an explanatory e-mail that presented the issue and made the recipients aware of the importance of their collaboration in this study. We tried to captivate the interest of these specialists in the subject and guaranteed them confidentiality of all data provided, which would only be used for statistical treatment and analysis.

In the selection of the population, it was taking into consideration the technicians with expertise in construction direction and management registered with the Portuguese Engineers Order that have participated in BIM based RC projects, and the 50 largest companies in the building construction and built heritage sector in Portugal according to PORDATA, the Portuguese Database with the major companies in Portugal resulting into 14 specialists. Although the sample (14 specialists) is small, it is representative of the Portuguese context, given its characteristics, size and criteria established for the selection.

The survey developed in the research study was divided into four distinct sections. Section I addressed the issue of AI and its impact on construction projects. Section II and Section III presented tables containing a range of factors carefully selected through a previous bibliographic compilation aimed at identifying the most important characteristics of RC (Section 1.2, Table 1) and its combination with the BIM methodology (Section 1.3, Table 2) in reducing AI. In Section IV respondents were asked to answer the following question: "Does national legislation provide for the reduction of AI? Would it be important to consider the use of RC or BIM? Why?".

In Section II and Section III respondents were asked to classify a set of characteristics using a Likert scale, rated from 1 to 4 , where 1 corresponded to "unimportant" and 4 to "very important" (Norman, 2010). After collecting the answers, we adopted the relative importance index (RII) determined for each item and defined by Eqn (1):

$$
\mathrm{RII}=\frac{\sum_{i=1}^{j} a_{i} \cdot n_{i}}{x . j} \times 100,
$$

where: $x$ - total number of survey responses $(14) ; j-$ number of levels defined as valid response options (4 in this case); $a_{i}$ - constant expressing the weight assigned to each response option $\left(0 \leq a_{i} \leq 1\right) ; n_{i}$ - variable expressing the frequency of selection of response $i$. The RII value ranges from 0 to 1, with a high RII showing a good correlation between the respondents' answers for each item.

To evaluate the internal consistency of the questionnaire, an analysis was performed using the Cronbach's alpha value to quantify the internal consistency of the items within each question. The Cronbach's alpha value can vary between 0 and 1 , so the higher the value between the items in the category, the higher the consistency, since this value measures the correlation between the answers to the questionnaire and presents the average correlation 
between the questions, which is calculated from the variance of the individual items and the variance of the sum of the items of each respondent in relation to all the items of each question in the questionnaire. This means that a respondent who has chosen a Likert value for a particular item tends to choose a similar numerical value for the other items. According to DeVellis (2003), a Cronbach's alpha value between 0.70 and 0.95 indicates a high internal consistency among all items; conversely, a Cronbach's alpha less than 0.70 presents a weak interrelationship among items (Tonglet et al., 2004).

\section{Analysis and discussion of results}

It was possible to obtain and validate all the answers from the 14 experts surveyed. Based on these answers, 78.6\% of these experts have more than 25 years of professional experience, and $21.4 \%$ have between 20 and 25 years of experience, and therefore all of them have experience in the public works sector in Portugal.

All the results obtained from the respondents' answers are explained and analysed below.

\subsection{Section I - Asymmetric information}

Section I was intended to obtain the respondents' assessment on the probability of AI occurring in construction projects and its impact using a scale from 1 to 5 , where 1 corresponded to "very low probability" and 5 to "very high probability".

Table 3 shows the results from the analysis of the collected data, based on the percentage calculated from the responses obtained. It can be observed that $64.3 \%$ of the respondents consider that $\mathrm{AI}$ can occur in construction projects in Portugal. Regarding the impact of AI, 57.1\% of the respondents also consider it to be very high, which, as
Table 3. Overall result of the research on the probability of AI occurring in construction projects and its impact

\begin{tabular}{|l|c|c|}
\hline \multicolumn{1}{|c|}{ Scale } & Probability of occurrence (\%) & Impact (\%) \\
\hline Very low & - & - \\
\hline Low & - & - \\
\hline Average & $14.3 \%$ & $14.3 \%$ \\
\hline High & $21.4 \%$ & $28.6 \%$ \\
\hline Very high & $64.3 \%$ & $57.1 \%$ \\
\hline
\end{tabular}

evidenced in the literature review, gives rise to a less efficient sector and a low level of productivity and innovation.

\subsection{Section II - Relational contracting as a method for reducing asymmetric information}

A correlation analysis in this section intended to obtain from respondents the predominant characteristics of RC that contributed to reducing AI. This section also sought to answer research question Q1 identified in the Introduction: "Does RC positively affect the reduction of AI in public works construction projects? What are the main characteristics of RC?".

Table 4 lists the sixteen characteristics (A1 to A16) found in the literature review (Section 1.2, Table 1), the corresponding RII values, Pearson's correlation and Cronbach's alpha.

The global Cronbach's alpha resulting from the analysis of the data collected from the general sample corresponds to 0.77 (above 0.75 ), which reveals a high internal consistency and therefore shows a good correlation between the respondents' answers. The individual values (by characteristic) of Cronbach's alpha shown in Table 4 suggest that each item contributes positively to internal consistency, as explained in Section 3.

Table 4. Main characteristics of RC that contribute to reducing AI (Cronbach's alpha $=0.7739$ )

\begin{tabular}{|c|c|c|c|}
\hline Characteristics of RC & RII & Pearson's correlation & Cronbach's alpha \\
\hline A1 - Information transfer in the project's initial phase & $89 \%$ & 0.9393 & 0.7868 \\
\hline A2 - Knowledge creation in the project's initial phase & $82 \%$ & 0.7683 & 0.7751 \\
\hline A3 - Reduction of conflicts between the parties involved & $86 \%$ & 0.9827 & 0.7337 \\
\hline A4 - Technological coordination between the parties involved & $80 \%$ & 0.6389 & 0.7690 \\
\hline A5 - Allocation of resources for effectively operating & $88 \%$ & 0.8944 & 0.7537 \\
\hline A6 - Risk sharing between the parties involved & $80 \%$ & 0.6389 & 0.7890 \\
\hline A7 - Distribution of responsibilities and risks & $88 \%$ & 0.8944 & 0.7401 \\
\hline A8 - Future relations between the parties involved & $75 \%$ & 0.7182 & 0.7228 \\
\hline A9 - Common incentives between the parties involved & $71 \%$ & 0.2863 & 0.7746 \\
\hline A10 - Involvement of the contractor in the project's initial phase & $75 \%$ & 0.7593 & 0.7940 \\
\hline A11 - Cooperation between the parties involved & $89 \%$ & 0.9393 & 0.7594 \\
\hline A12 - Its importance in complex projects & $93 \%$ & 0.9288 & 0.7481 \\
\hline A13 - Improving the attitude of project participants & $91 \%$ & 0.9478 & 0.7463 \\
\hline A14 - Reduction of disputes between the parties involved & $79 \%$ & 0.5153 & 0.7465 \\
\hline A15 - Decrease in scope and rework & $80 \%$ & 0.8305 & 0.7258 \\
\hline A16 - Increase in teamwork & $89 \%$ & 0.9393 & 0.8025 \\
\hline
\end{tabular}


The linear relationship between the characteristics of $\mathrm{RC}$ and Pearson's correlation shows a strong relationship between the variables, with the exception of characteristics A4 (Technological coordination between the parties involved), A6 (Risk sharing between the parties involved) and A14 (Reduction of disputes between the parties involved), which present values between 0.5 and 0.70 and therefore indicate a moderate correlation; and with the exception of characteristic A9 (Common incentives between the parties involved), which presents a value lower than 0.30 and therefore shows a weak correlation. This shows that respondents were more likely to assign inconsistent scores (according to Likert's scale) to characteristic A9.

Characteristic A9 also had a relatively low RII score, thus conveying some uncertainty in the respondents' response to the remaining characteristics. The best rated item is A12 (Its importance in complex projects), with a RII of 93\%, followed by A13 (Improving the attitude of project participants), with a RII of $91 \%$.

The analysis of the results shows that all respondents consider that the main characteristics of relational contracting positively affect the reduction of AI, with a RII of over $70 \%$. However, as a criterion of relevance, the five best-rated characteristics in reducing AI were the following: (i) Its importance in complex projects; (ii) Improving the attitude of project participants; (iii) Cooperation between the parties involved; (iv) Increased teamwork; and (v) Transfer of information in the project's initial phase.

\subsection{Section III - Relational contracting in combination with the BIM methodology in reducing asymmetric information}

A correlation analysis in Section III of the survey intended to find out from respondents which were the main characteristics of RC that, in combination with the BIM methodology, contribute to reducing IA. This section also sought to answer research question Q2 identified in the Introduction: "Does RC associated with BIM positively affect the reduction of $\mathrm{AI}$ in public works construction projects? What are the main characteristics of RC associated with BIM?".

Table 5 presents the seven characteristics (B1 to B7) identified in the literature review (Section 1.3, Table 2), the corresponding RII values, Pearson's correlation, and Cronbach's alpha.

The global Cronbach's alpha resulting from the analysis of the data collected from the general sample corresponds to 0.7818 (above 0.75 ), which reveals a high internal consistency and therefore indicates a good correlation between the respondent's answers. The individual values (by characteristic) of Cronbach's alpha shown in Table 5 suggest that each item contributes positively to internal consistency, as explained in Section 3, and also indicate as a strong relationship between all characteristics.

From the analysis of the results obtained, it is clear that all respondents consider that the main characteristics of RC in combination with the BIM methodology positively affect the reduction of AI, with a RII of over $84 \%$. However, as a criterion of relevance, the five bestrated characteristics in reducing AI were the following: (i) Facilitates adding information to the model; (ii) Interdependence among all project participants; (iii) Integrated activities with a single and mutual goal; (iv) Definition of roles and responsibilities; and (v) Increased communication between the parties involved.

\subsection{Section IV - National legislation on the use of collaborative systems}

Section IV of the survey intended to obtain respondents' opinion on the following question: "Should national legislation consider the use of the RC or the BIM methodology? Why?". This section also sought to answer research question Q3 identified in the Introduction: "Does the Portuguese legislation provide for the reduction of AI in public works construction projects?".

Respondents consider that the public procurement legislation does not provide for the reduction of AI and that it would be important to use RC in the Portuguese Public Contracts Code (PCC), particularly in management and division of responsibilities.

As to the introduction of the BIM methodology and $\mathrm{RC}$ in the Portuguese PCC to reduce AI in construction projects, $84.7 \%$ of respondents consider that it will be beneficial for the construction sector, and only $14.3 \%$ consider its introduction still early due to the interoperability of models and the mentality of companies regarding the use of RC.

Table 5. Main characteristics of RC in combination with the BIM methodology that contribute to reducing AI $($ Cronbach's alpha $=0.7818)$

\begin{tabular}{|l|l|l|l|}
\hline \multicolumn{1}{|c|}{ Characteristics of RC in combination with BIM } & \multicolumn{1}{|c|}{ RII } & \multicolumn{1}{|c|}{ Pearson's correlation } & Cronbach's alpha \\
\hline B1 - Corrects problems in data flow & $80 \%$ & 0.9759 & 0.7774 \\
\hline B2 - Facilitates adding information to the model & $89 \%$ & 0.9393 & 0.7074 \\
\hline B3 - Interdependence between all project participants & $89 \%$ & 0.9393 & 0.7514 \\
\hline B4 - Integrated activities with a single and mutual goal & $88 \%$ & 0.9778 & 0.7875 \\
\hline B5 - Involvement of designers and contractor to increase value for the client & $84 \%$ & 0.9965 & 0.7341 \\
\hline B6 - Increased communication between the parties involved & $86 \%$ & 0.9558 & 0.7217 \\
\hline B7 - Definition of roles and responsibilities & $88 \%$ & 0.8944 & 0.7882 \\
\hline
\end{tabular}




\section{Conclusions}

Information asymmetric has been a crucial issue in project management for a long time, and some participants are usually more informed about some facts, while others are less informed. The asymmetric information phenomenon is counterproductive in public works construction projects and it is found that in Portugal there is a high probability of asymmetric information occurring and having a strong impact on the sector. Contractors do not share the necessary information, which prevents them from getting involved in an integrated manner with the contracting parties. However, relational contracting supports different approaches that establish working relationships between stakeholders, involve win-win situations and enable better results, namely through the contractor's involvement in the project. The aim of this study was to find in the Portuguese public works construction sector the main characteristics of relation contracting and its combination with the BIM methodology. Based on a survey conducted with specialists with solid experience and knowledge in construction projects and BIM-IPD contracts, it was found that the probability of asymmetric information occurring in the Portuguese construction sector is very high and its impact is equally high. It can be concluded that the reduction of asymmetric information in public works construction projects is positively affected by relation contracting, with an average RII of $83 \%$ (Q1), and by the combination of relation contracting with the BIM methodology, with an average RII of $86 \%$ (Q2). Regarding the main characteristics of relation contracting (Q1), it can be observed that it has a special relevance in complex projects, improves the attitude of project participants, promotes the cooperation of the parties involved, and increases teamwork and, consequently, information sharing since the beginning of the project. On the other hand, the combination of relation contracting with the BIM methodology (Q2) facilitates adding information to the model, promotes a single and mutual goal as a result of increased communication and the correct definition of the roles and responsibilities of all project participants. Finally, $84.7 \%$ of respondents consider it important to introduce the BIM methodology and relation contracting into the Portuguese Public Contracts Code to reduce asymmetric information and refer that the current national legislation does not provide for the reduction of asymmetric information, but they highlight its importance, particularly in the division of responsibilities.

The major conclusion that we draw from our analysis is that the improved transparency from the use of BIM and relational contracting reduce the risk of information asymmetry. The risk of information asymmetry makes the information directly accessible by anyone at any time and ensures that the same information represented in the same way. The potential of BIM for sharing and visualizing information as well as considering changes in design and during execution, allows it to be shared transparently to the stakeholders, and reduce asymmetry information.

This study is limited by the number of technicians with expertise in construction direction and management that have participated in BIM based IPD projects. A wider study needs to be carried out covering more cases across other countries.

Future research can focus on the assessment of knowledge management and its impact on reducing of asymmetric information in construction projects, as well as on analyses based on case studies in construction companies regarding the advantages of relation contracting in combination with the BIM methodology in the management of construction projects. The use of contract theory to examine how issues such as information asymmetry, adverse selection, opportunistic behaviour, and moral hazards materialise during the BIM Methodology in construction projects.

\section{Data availability statement}

No data, models, or code were generated or used during the study.

\section{Disclosure statement}

Authors have no competing financial, professional, or personal interests from other parties related to this research study.

\section{References}

American Institute of Architects, \& Associated General Contractors of America. (2004). Primer on project delivery. http://content.aia.org/sites/default/files/2017-08/AIA-AGC-Primer-onProject-Delivery-Terms.pdf

Acıkara, T., Kazaz, A., \& Ulubeyli, S. (2017). Evaluations of construction project participants' attitudes toward quality management in Turkey. Procedia Engineering, 196, 203-210. https://doi.org/10.1016/j.proeng.2017.07.192

Addor, M. R. A., de Almeida Castanho, M. D., Cambiaghi, H., Delatorre, J. P. M., Nardelli, E. S., \& de Oliveira, A. L. (2010). Colocando o "i” no BIM. Usjt - Arq.Urb, 4, 104-115.

Akerlof, G. A. (1970). The market for 'lemons': Quality uncertainty and the market mechanism. The Quarterly Journal of Economics, 84(3), 488-500. https://doi.org/10.2307/1879431

Alon, I., Boulanger, M., Misati, E., \& Madanoglu, M. (2015). Are the parents to blame? Predicting franchisee failure. Competitiveness Review, 25(2), 205-217. https://doi.org/10.1108/CR-10-2014-0034

Anysz, H. (2019). Modelling negotiations of construction subcontract based on a game theory - results of an experiment. IOP Conference Series: Materials Science and Engineering, 603, 032005. https://doi.org/10.1088/1757-899X/603/3/032005

Arayici, Y., Khosrowshahi, F., Marshal Ponting, A., \& Mihindu, S. (2009). Towards implementation of building information modelling in the construction industry. In Fifth International Conference on Construction in the 21st Century (CITC-V) "Collaboration and Integration in Engineering, Management and Technology". Istanbul, Turkey.

Arrow, K. J. (1978). Uncertainty and the welfare economics of medical care. In P. Diamond \& M. Rothschild (Eds.), Uncertainty in Economics (Vol. 53, Issue 5, pp. 345-375). Elsevier. https://doi.org/10.1016/B978-0-12-214850-7.50028-0 
Azhar, S. (2011). Building information modeling (BIM): Trends, benefits, risks, and challenges for the AEC industry. Leadership and Management in Engineering, 11(3), 241-252. https://doi.org/10.1061/(ASCE)LM.1943-5630.0000127

Azhar, S., Khalfan, M., \& Maqsood, T. (2012). Building information modeling (BIM): Now and beyond. Australasian Journal of Construction Economics and Building, 12(4), 15-28. https://doi.org/10.5130/AJCEB.v12i4.3032

Biglaiser, G., \& Friedman, J. W. (1999). Adverse selection with competitive inspection. Journal of Economics and Management Strategy, 8(1), 1-32. https://doi.org/10.1162/105864099567569

Bloodgood, J. M., \& Salisbury, W. D. (2001). Understanding the influence of organizational change strategies on information technology and knowledge management strategies. Decision Support Systems, 31(1), 55-69. https://doi.org/10.1016/S0167-9236(00)00119-6

Bovens, M., Goodin, R. E., Schillemans, T., \& Gailmard, S. (2014). Accountability and principal-agent theory. In M. Bovens, R. E. Goodin, \& T. Schillemans (Eds.), The Oxford handbook of public accountability. Oxford University Press. https://doi.org/10.1093/oxfordhb/9780199641253.013.0016

Chang, A. S., \& Shen, F.-Y. (2014). Effectiveness of coordination methods in construction projects. Journal of Management in Engineering, 30(3), 04014008.

https://doi.org/10.1061/(ASCE)ME.1943-5479.0000222

Chappell, M., \& Parkin, I. D. (2004). Management of construction. In G. F. Read (Ed.), Sewers: Replacement and new construction (pp. 224-235). Elsevier. https://doi.org/10.1016/B978-075065083-0/50012-8

Charef, R., Alaka, H., \& Emmitt, S. (2018). Beyond the third dimension of BIM: A systematic review of literature and assessment of professional views. Journal of Building Engineering, 19, 242-257. https://doi.org/10.1016/j.jobe.2018.04.028

DeVellis, R. F. (2003). Scale development: Theory and applications (2nd ed., Vol. 26). Sage Publications.

Directive 2014/24/EU of the European Parliament and of the Council of 26 February 2014 on public procurement and repealing Directive 2004/18/EC Text with EEA relevance. (2014). Official Journal of the European Union, 65-242.

Doornik, K. (2006). Relational contracting in partnerships. Journal of Economics and Management Strategy, 15(2), 517-548. https://doi.org/10.1111/j.1530-9134.2006.00109.x

Dumouchel, B., Albert, A., \& Stogaitis, G. (2004). Project manager competency development framework. Project Management Institute.

EuBIM TaskGroup. (2017). Manual relativo à aplicação da Modelação da Informação da Construção (BIM) no Setor Público Europeu (in Portuguese). http://www.eubim.eu/wp-content/ uploads/2018/03/GROW-2017-01356-00-00-PT-TRA-00.pdf

Fanning, B., Clevenger, C. M., Ozbek, M. E., \& Mahmoud, H. (2015). Implementing BIM on infrastructure: Comparison of two bridge construction projects. Practice Periodical on Structural Design and Construction, 20(4), 04014044. https://doi.org/10.1061/(ASCE)SC.1943-5576.0000239

Ghosh, A. (2020). Potential of building integrated and attached/ applied photovoltaic (BIPV/BAPV) for adaptive less energyhungry building's skin: A comprehensive review. Journal of Cleaner Production, 276, 123343.

https://doi.org/10.1016/j.jclepro.2020.123343

Gneezy, U., Rey-Biel, P., \& Meier, S. (2011). When and why Incentives (don't) work to modify behavior. Journal of Economic Perspectives, 25, 191-210. https://doi.org/10.1257/jep.25.4.191

Grafton, J., \& Mundy, J. (2017). Relational contracting and the myth of trust: Control in a co-opetitive setting. Management Accounting Research, 36, 24-42.

https://doi.org/10.1016/j.mar.2016.07.008
Grilo, A., \& Jardim-Goncalves, R. (2010). Value proposition on interoperability of BIM and collaborative working environments. Automation in Construction, 19(5), 522-530.

https://doi.org/10.1016/j.autcon.2009.11.003

$\mathrm{Gu}, \mathrm{N}$., \& London, K. (2010). Understanding and facilitating BIM adoption in the AEC industry. Automation in Construction, 19(8), 988-999. https://doi.org/10.1016/j.autcon.2010.09.002

Halttula, H., Aapaoja, A., \& Haapasalo, H. (2015). The contemporaneous use of building information modeling and relational project delivery arrangements. Procedia Economics and Finance, 21(15), 532-539.

https://doi.org/10.1016/s2212-5671(15)00209-9

Hamidavi, T., Abrishami, S., \& Hosseini, M. R. (2020). Towards intelligent structural design of buildings: A BIM-based solution. Journal of Building Engineering, 32, 101685.

https://doi.org/10.1016/j.jobe.2020.101685

Hardin, B., \& McCool, D. (2015). BIM and construction management: Proven tools, methods, and workflows (2nd ed.). John Wiley \& Sons Inc.

Hardy, C., \& Phillips, N. (1998). Strategies of engagement: Lessons from the critical examination of collaboration and conflict in an interorganizational domain. Organization Science, 9(2), 217-230. https://doi.org/10.1287/orsc.9.2.217

Hart, O. (2017). Incomplete contracts and control. American Economic Review, 107(7), 1731-1752. https://doi.org/10.1257/aer.107.7.1731

He, Q., Wang, G., Luo, L., Shi, Q., Xie, J., \& Meng, X. (2017). Mapping the managerial areas of Building Information Modeling (BIM) using scientometric analysis. International Journal of Project Management, 35(4), 670-685.

https://doi.org/10.1016/j.ijproman.2016.08.001

Healy, P. (2007). Project management in construction. In R. Best \& G. de Valence (Eds.), Design and construction (Chapter 11). John Wiley \& Sons, Ltd. https://doi.org/10.4324/9780080491080

Herz, H., Schmutzler, A., \& Volk, A. (2019). Cooperation and mistrust in relational contracts. Journal of Economic Behavior \& Organization, 166, 366-380.

https://doi.org/10.1016/j.jebo.2019.07.007

Holmström, J., Singh, V., \& Främling, K. (2015). BIM as infrastructure in a Finnish HVAC actor network: Enabling adoption, reuse, and recombination over a building life cycle and between projects. Journal of Management in Engineering, 31(1), A4014006.

https://doi.org/10.1061/(ASCE)ME.1943-5479.0000305

Hosseini, A., Haddadi, A., Andersen, B., Olsson, N., \& Lædre, O. (2017). Relational base contracts - Needs and trends in Northern Europe. Procedia Computer Science, 121, 10881095. https://doi.org/10.1016/j.procs.2017.11.139

Hrelja, R., Rye, T., \& Mullen, C. (2018). Partnerships between operators and public transport authorities. Working practices in relational contracting and collaborative partnerships. Transportation Research Part A: Policy and Practice, 116, 327338. https://doi.org/10.1016/j.tra.2018.06.032

Jones, B. (2014). Integrated project delivery (IPD) for maximizing design and construction considerations regarding sustainability. Procedia Engineering, 95, 528-538.

https://doi.org/10.1016/j.proeng.2014.12.214

Kent, D. C., \& Becerik-Gerber, B. (2010). Understanding construction industry experience and attitudes toward integrated project delivery. Journal of Construction Engineering and Management, 136(8), 815-825.

https://doi.org/10.1061/(ASCE)CO.1943-7862.0000188 
Kurwi, S., Demian, P., \& Hassan, T. M. (2017). Integrating BIM and GIS in railway projects: A critical review. In Proceedings of the $33^{\text {rd }}$ Annual ARCOM Conference (pp. 45-53). Cambridge, UK, Association of Researchers in Construction Management.

Laffont, J.-J., \& Martimort, D. (2009). The theory of incentives. Princeton University Press. https://doi.org/10.2307/j.ctv7h0rwr

Lévy, F. (2011). BIM in small-scale sustainable design. John Wiley \& Sons. https://doi.org/10.1002/9781119572619

Li, X., Wu, P., Shen, G. Q., Wang, X., \& Teng, Y. (2017). Mapping the knowledge domains of Building Information Modeling (BIM): A bibliometric approach. Automation in Construction, 84, 195-206. https://doi.org/10.1016/j.autcon.2017.09.011

Ling, F. Y. Y., Ong, S. Y., Ke, Y., Wang, S., \& Zou, P. (2014). Drivers and barriers to adopting relational contracting practices in public projects: Comparative study of Beijing and Sydney. International Journal of Project Management, 32(2), 275-285. https://doi.org/10.1016/j.ijproman.2013.04.008

Ling, F. Y. Y., \& Tran, P. Q. (2012). Effects of interpersonal relations on public sector construction contracts in Vietnam. Construction Management and Economics, 30(12), 1087-1101. https://doi.org/10.1080/01446193.2012.729848

Liu, Y., van Nederveen, S., \& Hertogh, M. (2017). Understanding effects of BIM on collaborative design and construction: An empirical study in China. International Journal of Project Management, 35(4), 686-698.

https://doi.org/10.1016/j.ijproman.2016.06.007

Marinho, A. J. C. (2014). Aplicação do Building Information Modeling na gestão de projetos de construção. Universidade do Minho (in Portuguese).

Matthews, O., \& Howell, G. A. (2005). Integrated project delivery an example of relational contracting. Lean Construction Journal, 2(1), 46-61.

Mesa, H. A., Molenaar, K. R., \& Alarcón, L. F. (2016). Exploring performance of the integrated project delivery process on complex building projects. International Journal of Project Management, 34(7), 1089-1101.

https://doi.org/10.1016/j.ijproman.2016.05.007

Mihic, M., Sertic, J., \& Zavrski, I. (2014). Integrated project delivery as integration between solution development and solution implementation. Procedia - Social and Behavioral Sciences, 119, 557-565. https://doi.org/10.1016/j.sbspro.2014.03.062

Mok, M. K. Y., \& Shen, G. Q. (2016). A network-theory based model for stakeholder analysis in major construction projects. Procedia Engineering, 164, 292-298.

https://doi.org/10.1016/j.proeng.2016.11.622

Morais, N. M., Forte, S. H. A. C., De Oliveira, O. V., \& Do Carmo Sobreira, M. (2015). Proposition of a method to evaluate the maturity of scenario analysis inside organizations. Revista de Administracao Mackenzie, 16(2), 214-244.

https://doi.org/10.1590/1678-69712015/administracao. v16n2p214-244

Musawir, A. ul, Abd-Karim, S. B., \& Mohd-Danuri, M. S. (2020). Project governance and its role in enabling organizational strategy implementation: A systematic literature review. International Journal of Project Management, 38(1), 1-16. https://doi.org/10.1016/j.ijproman.2019.09.007

Nathan, A. J., \& Scobell, A. (2012). How China sees America: The sum of Beijing's fears. Foreign Affairs, 91(5), 32-47.

Ning, Y., \& Ling, F. Y. Y. (2015). The effects of project characteristics on adopting relational transaction strategies. International Journal of Project Management, 33(5), 998-1007. https://doi.org/10.1016/j.ijproman.2014.12.006
Norman, G. (2010). Likert scales, levels of measurement and the "laws" of statistics. Advances in Health Sciences Education, 15(5), 625-632. https://doi.org/10.1007/s10459-010-9222-y

Piroozfar, P., Farr, E. R. P., Zadeh, A. H. M., Timoteo Inacio, S., Kilgallon, S., \& Jin, R. (2019). Facilitating building information modelling (BIM) using integrated project delivery (IPD): A UK perspective. Journal of Building Engineering, 26, 100907. https://doi.org/10.1016/j.jobe.2019.100907

Project Management Institute. (1996). A guide to the project management body of knowledge.

Project Management Institute. (2018). The PMI guide to business analysis ( $1^{\text {st }}$ ed.). https://www.pmi.org/pmbok-guidestandards/foundational/business-analysis

Popp, R., Armour, T., Senator, T., \& Numrych, K. (2004). Countering terrorism through information technology. Communications of the ACM, 47(3), 36-43. https://doi.org/10.1145/971617.971642

Rahman, M. M., \& Kumaraswamy, M. M. (2002). Joint risk management through transactionally efficient relational contracting. Construction Management and Economics, 20(1), 45-54. https://doi.org/10.1080/01446190110089682

Raisbeck, P., Millie, R., \& Maher, A. (2010). Assessing integrated project delivery: A comparative analysis of ipd and alliance contracting procurement routes. In Proceedings of the 26th Annual ARCOM Conference (pp. 1019-1028). Leeds, UK, Association of Researchers in Construction.

Ribeiro, D. C. (2012). 85-Avaliação Da Aplicabilidade Do Ipd Em Portugal (Issue 1). Universidade do Porto. https://hdl.handle.net/10216/68182

Rothschild, M., \& Stiglitz, J. (1976). Equilibrium in competitive insurance markets: An essay on the economics of imperfect information. Quarterly Journal of Economics, 90(4), 629-649. https://doi.org/10.2307/1885326

Rzepecki, Ł. (2021). Application of game theory against nature in supporting bid pricing in construction. Symmetry, 13(1), 132. https://doi.org/10.3390/sym13010132

Sackey, E., Tuuli, M., \& Dainty, A. (2015). Sociotechnical systems approach to BIM implementation in a multidisciplinary construction context. Journal of Management in Engineering, 31(1), 401-405.

https://doi.org/10.1061/(ASCE)ME.1943-5479.0000303

Sanders, S. R., \& Moore, M. M. (1992). Perceptions on partnering in the public sector. Project Management Journal, 23(4), $13-19$.

Schmidt, C. G., \& Wagner, S. M. (2019). Blockchain and supply chain relations: A transaction cost theory perspective. Journal of Purchasing and Supply Management, 25(4), 100552. https://doi.org/10.1016/j.pursup.2019.100552

Spender, J. C. (1993). Competitive advantage from tacit knowledge? Unpacking the concept and its strategic implications. Academy of Management Proceedings, 1993(1), 37-41. https://doi.org/10.5465/ambpp.1993.10315222

SPMS. (2017). Código dos contratos públicos (in Portuguese). http://www.contratacaopublica.com.pt/legislacao/

Su, P., Peng, Y., Hu, Q., \& Tan, R. (2020). Incentive mechanism and subsidy design for construction and demolition waste recycling under Information asymmetry with reciprocal behaviors. International Journal of Environmental Research and Public Health, 17, 4346. https://doi.org/10.3390/ijerph17124346

Succar, B. (2009). Building information modelling framework: A research and delivery foundation for industry stakeholders. Automation in Construction, 18(3), 357-375. https://doi.org/10.1016/j.autcon.2008.10.003 
Succar, B., \& Kassem, M. (2015). Macro-BIM adoption: Conceptual structures. Automation in Construction, 57, 64-79. https://doi.org/10.1016/j.autcon.2015.04.018

Teng, Y., Li, X., Wu, P., \& Wang, X. (2017). Using cooperative game theory to determine profit distribution in IPD projects. International Journal of Construction Management, 19(1), 32-45. https://doi.org/10.1080/15623599.2017.1358075

Tilles, P. F. C., Ferreira, F. F., Francisco, G., Pereira, C. de B., \& Sarti, F. M. (2011). A Markovian model market - Akerlof's lemons and the asymmetry of information. Physica A: Statistical Mechanics and Its Applications, 390(13), 2562-2570. https://doi.org/10.1016/j.physa.2011.03.007

Tonglet, M., Phillips, P. S., \& Read, A. D. (2004). Using the theory of planned behaviour to investigate the determinants of recycling behaviour: a case study from Brixworth, UK. Resources, Conservation and Recycling, 41(3), 191-214. https://doi.org/10.1016/j.resconrec.2003.11.001

Walker, D. H. T., \& Lloyd Walker, B. M. (2015). Collaborative project procurement arrangements. Project Management Institute, Inc.

Wang, L., Kunc, M., \& Bai, S. (2017). Realizing value from project implementation under uncertainty: An exploratory study using system dynamics. International Journal of Project Management, 35(3), 341-352.

https://doi.org/10.1016/j.ijproman.2017.01.009

Wang, Y., Thangasamy, V. K., Hou, Z., Tiong, R. L. K., \& Zhang, L. (2020). Collaborative relationship discovery in BIM project delivery: A social network analysis approach. Automation in Construction, 114, 103147. https://doi.org/10.1016/j.autcon.2020.103147

Xiang, P., Huo, X., \& Shen, L. (2015). Research on the phenomenon of asymmetric information in construction projects - The case of China. International Journal of Project Management, 33(3), 589-598.

https://doi.org/10.1016/j.ijproman.2014.10.007

Xiang, P., Zhou, J., Zhou, X., \& Ye, K. (2012). Construction project risk management based on the view of asymmetric information. Journal of Construction Engineering and Management, 138(11), 1303-1311.

https://doi.org/10.1061/(ASCE)CO.1943-7862.0000548

Yiu, T. W., Liu, T., \& Kwok, L. C. (2018). Explicating the role of relationship in construction claim negotiations. Journal of Construction Engineering and Management, 144(2), 04017114. https://doi.org/10.1061/(ASCE)CO.1943-7862.0001431

You, J., Chen, Y., Wang, W., \& Shi, C. (2018). Uncertainty, opportunistic behavior, and governance in construction projects: The efficacy of contracts. International Journal of Project Management, 36(5), 795-807. https://doi.org/10.1016/j.ijproman.2018.03.002

Young, H. P. (2015). The evolution of social norms. Annual Review of Economics, 7(1), 359-387.

https://doi.org/10.1146/annurev-economics-080614-115322 